\title{
RANCANG BANGUN SISTEM PRODUKSI DAN PERSEDIAAN UMKM
}

\author{
Rinci Kembang Hapsari ${ }^{1}$, Azmuri Wahyu Azinar ${ }^{2}$, Sugiyanto ${ }^{3}$ \\ ${ }^{1}$ Teknik Informatika, Ieknologi Adhi Tama Surabaya, Indonesia \\ Email: ${ }^{1}$ rincikembang@itats.ac.id Email: ${ }^{2}$ azmuri@itats.ac.id Email: ${ }^{3}$ sugiyanto@itats.ac.id
}

\begin{abstract}
The large contribution of MSMEs is as a driver of the nation's economy which is proven to be resistant to various shocks to the economic crisis. In operational records, MSMEs still use manual systems and there are even those that are not recorded properly. Even in the production process that functions to determine the cost of production and production control also still using manual methods. So that a computerized system is needed in the production process that can automatically calculate the cost of production, control the production and inventory stock. Based on testing and analysis, it can be proven that the applications built are very helpful to MSMEs, especially in the production process because data processing can be done quickly and accurately. With the computerized application system produced, it can monitor production results and control stock items. So that it can minimize the accumulation of goods stock production and the occurrence of empty stock for a long time. With this application system can also help MSMEs in determining the cost of production automatically.
\end{abstract}

Keywords: MSMEs, systems, production, inventory, reports

\section{PENDAHULUAN}

\section{Latar Belakang}

Usaha Mikro Kecil dan Menengah (UMKM) merupakan salah satu penggerak perekonomian bangsa yang terbukti tahan terhadap berbagai goncangan krisis ekonomi. Berdasarkan data Kementrian Koperasi dan UMKM hingga tahun 2012 jumlah pelaku UMKM mencapai 56.534.592 unit usaha dan terus meningkat, serta dapat menyerap tenaga kerja hingga 107.657.510 jiwa.

Dalam menjalankan perannya UMKM dituntut agar bisa melakukan sistem manajemen yang bagus, baik dari sisi produksi, persediaan, penjualan, sampai akuntansi. Saat ini sistem manajemen informasi yang digunakan di UMKM masih menggunakan sistem manual bahkan ada yang tidak tercatat dengan baik. Sehingga pengelola atau Owner sering susah untuk menentukan keputusan bisnis.

Dalam proses produksi salah satu fungsi yang sangat penting adalah menghitung harga pokok produksi. Kesalahan dalam perhitungan harga pokok produksi akan mengakibatkan kesalahn dalam penentuan harga jual. Adanya kesalahn harga jual bisa menyebabkan kerugian pada perusahaan karena harga jual sama atau lebih kecil dari harga pokok produksi, atau juga bila harga jual terlalu tinggi mengakibatkn kalah bersaing dengan produk dari perusahaanlain.Selain berfungsi untuk penentuan harga pokok produski, fungsi lainnya adalah sebagai kontrol proses produksi.

Oleh karena itu, perlu diadakan perbaikan sistem pada proses produksi, persediaan, dan pembuaan laporan. Dengan sistem terkomputerisasi data dapat diinput dan menyajikan informasi dengan jelas. Dengan adanya sistem ini diharapkan dapat mempermudah karyawan dalam pelaksanaan tugas dan pencatatan dalam bidang produksi,persediaandan menyiapkan laporan kepada atasannya dengan lebih efisien 


\section{Landasan Teori}

\section{Sistem Produksi}

Sistem produksi merupakan kumpulan dari sub sistem yang saling berinteraksi dengan tujuan mentransformasi input produksi menjadi output produksi. Input produksi ini dapat berupa bahan baku, mesin, tenaga kerja, modal dan informasi sedangkan output produksi merupakan produk yang dihasilkan berikut sampingannya seperti limbah, informasi.[1]

Aktivitas produksi merupakan bagian dari fungsi organisasi perusahaan yang bertanggung jawab terhadap pengolahan bahan baku menjadi produk yang dapat dijual. Dalam melaksanakan fungsi produksi tersebut, diperlukan rangkain kegiatan yang akan membentuk suatu sistem produksi, yang terdiri dari tiga fungsi utama, yaitu : 1) Proses produksi, yaitu metode dan teknik yang digunakandalam mengolah bahan baku menjadi produk; 2) Perencanaan produksi, yaitu merupakan tindakan antisipasi dimasa mendatang sesuai dengan periode waktu yang direncanakan; 3) Pengendalian produksi, yaitu tindakan yang menjamin bahwa semua kegiatan yang dilaksanakan dalam perencanaan telah dilakukan sesuai dengan target yang telah ditetapkan.[2]

Dalam sistem produksi dapat dilakukan perhitungan terhadapbesarnya biay produksi, proses produksi dan hasil produksi. Sehingga dalam sistem informasi produksi, hasil yang dibutuhkan dapat memperhitungkan biaya bahan, biaya operasional dan keuangan yang akan didapatkan dari hasil produk untuk setiap produksi.

\section{Desain respon terhadap permintaan konsumen}

Dalam merespon permintaan konsumen yang diwujudkan dalam bentuk desain terdapat beberapa cara,karena tergantung dari permintaan konsumen, yaitu :

a. Engineer To Order (ETO), sistem produksi dimana produk dibuat setelah mendesain., perusahaan tidak membuat produk itu sebelumnya. Sehingga desain baru dibuat setelah ada permintaandari pelanggan, yang biasanya memiliki spesifik-spsifik tertentu yang tidak ada dalam produk-produk sebelumnya.

b. Make to Order (MTO), sistem produksi dimana produk dibuat setelah ada pesanan. Jadi perusahaan hanya mempunyai desain produk dan beberapa material standar dalam sistem inventori dari produk-produk yang telah dibuat sebelumnya. MTO biasanya digunakan jika produk yang dihasilkan kualitasnya agak rendah dan variabelnya cukup tinggi.

c. Assemble to Order (ATO), sistem produksi dimana produk di assembly setelah ada order (komponen-komponen penyusunnya sudah terproduksi). Perusahaan memiliki inventori yang terdiri dari semua sub assemblies atau modul-modul. Apabila pelanggan memesan produk lagi dengan spesifikasi yang sama, produsen secara cepat merakit modul yang ada dan mengirimkan dalam bentuk produk akhir ke pelanggan. ATO biasanya digunakan jika produk yang dihasilkan kuantitasnya cukup tinggi dan variabilitas agak rendah.

d. Make to Stock (MTS), Sistem produksi dimana produk dibuat secara massal dan siap didistribusikan kepada konsumen. Perusahaan memiliki inventori yang terdiri dari produk akhir (finished product) untuk di kirim kepada pelanggan. MTS biasanya digunakan jika produk yang dihasilkan memiliki kuantitas tinggi dan variabilitas rendah

\section{Harga Pokok Produksi}

Hansen dan Mowen menyatakan bahwa harga pokok produksi mencerminkan total biaya barang yang diselesaikan selama periode berjalan.[3] Harga pokok produksi juga 
disebut biaya produksi. Sedangkan menurut Raiborn dan Kinney harga pokok produksi adalah total produksi biaya barang-barang yang telah selesai dikerjakan dan ditransfer ke dalam persediaan baraang jadi selama satu periode[4].

Dari definisi diatas dapat ditarik kesimpulanbahwa harga pokok produksi adalah total biaya yang dikeuarkan untukmngolah bahan baku menjadi produk jadi selama periode berjalan. Dimana menurut Carter unsur-unsur harga pokok produksi mecakup tiga hal yaitu [5] :

a) Biaya bahan baku langsung (direct material cost) adalah semua bahan baku yang membentuk bagian integral dari produk jadi dan dimasukkan secara eksplisit dalam perhitungan biaya produk. Biaya bahan baku langsung meliputi plat stainless, hollo dan pipa bulat stainless.

b) Biaya tenaga kerja langsung (direct labor cost) adalah tenaga kerja yang melakukan konversi bahan baku langsung menjadi produk jadi dan dapat di bebankan secara layak ke produk tertentu. Biaya tenaga kerja langsung meliputi upah tenaga kerja yang dipekerjakan.

c) Biaya overhead pabrik (factory overhead) terdiri atas semua biaya manufaktur yang tidak ditelusuri secara langsung ke output tertentu. Biaya overhead pabrik meliputi biaya listrik dan biaya penyusutan mesin.

Metode memperhitungkan unsur-unsur biaya ke dalam harga pokok produksi terdapat dua factor pendekatan, yaitu[6] :

a) Full Costing, metode penentuan harga pokok produk yang menghitung semua unsur biaya bahan baku, biaya tenaga kerja langsung dan biaya overhead baik yang berperilaku variabel maupun tetap. Harga pokok produksi menurut metode full costing terdiri dari unsur-unsur biaya produksi sebagai berikut:

Biaya bahan baku

$\mathrm{XxX}$

Biaya tenaga kerja langsung $\quad \mathrm{xxx}$

Biaya overhead pabrik variable $\quad \mathrm{xxx}$

Biayaoverhead pabrik tetap $\quad \underline{\mathrm{xxx}}+$

Harga pokok produksi $\quad \mathbf{x x x x}$

b) Varable Costing,merupakan perhitungan harga pokok produk yang hanya memasukkan biaya produksi variabel. Biaya yang bersifat tetap terhadap produk (BOP tidak tetap) dimasukkan sebagai biaya periode. Metode variabel costing dapat digambarkan sebagai berikut :

$\begin{array}{ll}\text { Biaya bahan baku } & \mathrm{xxx} \\ \text { Biaya tenaga kerja langsung } & \mathrm{xxx} \\ \text { Biaya overhead pabrik variable } & \underline{\mathbf{x x x}}+ \\ \text { Harga pokok produksi } & \mathbf{x x x x}\end{array}$

\section{Persediaan}

Pengendalian persediaan barang atau bahan baku harus dilaksanakan seefektif mungkin dalam suau perusahan untukmencegah dan menghindari terjadinya kelebihan maupun kekurangan persediaan. Dalam bidang industri persediaan memiliki peran sangat penting karena memiliki peranan yang berpengaruh terhadap keuntungan perusahan dan menentukan kontinuitas dariakivias perusahaan.

Menurut Rangkuti pengertian persdiaan merupakan suatu aktiva yang meliputi barangbarang perusahaan dengan maksud untuk dijual dalam suatu periode usaha tertentu, atau persediaan barang masih dalam pengerjaan/proses produksi ataupun persediaan barang baku yang masih menunggu penggunaannya suatu proses produksi [7] 


\section{METODE PENELITIAN}

\section{Metode Pengumpulan Data}

$>$ Observasi

Observasi dilakukan dengan melihat langsung kegiatan operasional produksi yang berjalan pada 10 UMKM yang berada di kota Surabaya, Gresik dan Sidoarjo. Dengan melihat kegiatan fisik dan mengamati proses pencatatan data dan informasi yang berjalan pada kegiatan produksi di UMKM tersebut.

$>$ Wawancara

Wawancara dilakukan dengan mengajukan pertanyaan ke pihak terkait seputar proses manajemen produksi pada 10 UMKM di kota Surabaya, Gresik dan Sidoarjo. Tahapan wawancara menghasilkan informasi seputar kegiatan opersional bisnis dan keterangan seputar perusahaan.

$>$ Studi Literatur

Studi literature dilakukan dengan mempelajari danmemahami berbagai sumber literasi yang berhubungan dengan penelitian ini, terkait persediaan, metode perhitungan hpp dan akuntansi. Sumber literasi berasal dari buku maupun jurnal.

Dewi[8] dalam telah melakukan penelitian terkait dengan perancangan sistem informasi perencanaan dan pengendalian bahan baku pada industry pakaian. Stephanie[9] juga telah melakukan penelitian perancangan sistem produksi, persdiaan dan pembelian. Pada kedua penelitian berfokuskan pada manajemen produksi dan stok belum ada pembahasan terkait perhitngan harga pokok produksi yang juga dibutuhkan sebagai dasar penentuan harga jual.

Dalam penelitian ini di bahas terkait perancangan dan pengembangan sistem informasi mencakup proses produksi, kontrol stok dan perhitungan harga pokok penjualan

\section{Analisa Kebutuhan dan Desain Sistem}

$>$ Analisa Kebutuhan

Dalam perancangan ini metode yang digunakan penulis adalah metod view conroller (MVC). Dilakukan analisa kebutuhan terhadap sistem yang akan dibuat. Pada tahapan analisa kebutuhn digali kebuuhan fungsional dan kebutuhan non fungsionaldari sistem yang dibangun.

$>$ Desain sistem

Melakukan perancangan sistem terhadap solusi dari permasalahan yang ada dengan membuat rancangan UML. Diagram UML yang dibuat menggunakan Use Case Diagram, Activity Diagram, Sequence Diagram, dan Class Diagram.

\section{HASIL DAN PEMBAHASAN}

\section{Analisa Kebutuhan}

Dalam pengembangan sistem terkomputerisasi yang dilakukan dalam penelitian ini terdapat fungsi-fungsi yang harus dikemebangkan,yaitu:

a) Fungsi Login, merupakan kunci untuk setiap user dalam menjlankan sistem terkomputerisasi. Dengan adanya fungsi ini konsep multi user dan autorisasi user bisa diterapkan. Sehingga setiap aktifitas yang ada bisa diketahui siapa yang melakukannya.

b) Fungsi Kelola data master, fungsi ini akan melakukan pengelolaan data master. Dimana terdapat beberapadata master, yaitu master barang, master kategori, master gudang dan master produksi. 
Kelola master barang digunakan untuk menmbahkan data barang baru, mengedit data barang yang sudah ada. Jika ada data barang yang sudah tidak digunakan maka dalam fungsi ini dapat dilakukan menon-aktifkan data barang tersebut. Dalam mengkontrol persediaan barang, dalam master barang juga diberikanfasilitas untuk mencatat jumlah stok minimum dan jumlah stok maksimum.

c) Fungsi Mutasi Gudang, fungsi ini digunakan untuk menginputkan item-item barang yang akan dipindahkan dari gudang asal ke gudang tujuan. Sehingga kontrol mutasi barang antar gudang dapat terpantau dan stok barang per gudang bisa akurat.

d) Fungsi Produksi, fungsi produksi digunakan untuk menginputkan item produksi yang dilakukan setiap saat. Dimana ketika menginput produksi, secara otomatis akan memotong stok bahan baku serta menambah stok produk jadinya.

e) Fungsi Pembelian, fungsi ini digunakan untuk menginputkan data barang dan kuantitas pembelian.

f) Fungsi Re-calculate stok, fungsi ini akan dilakukan secara otomatis setiap kali dilakukan proses pembelian, mutasi barng antar gudang,dan proses produksi.

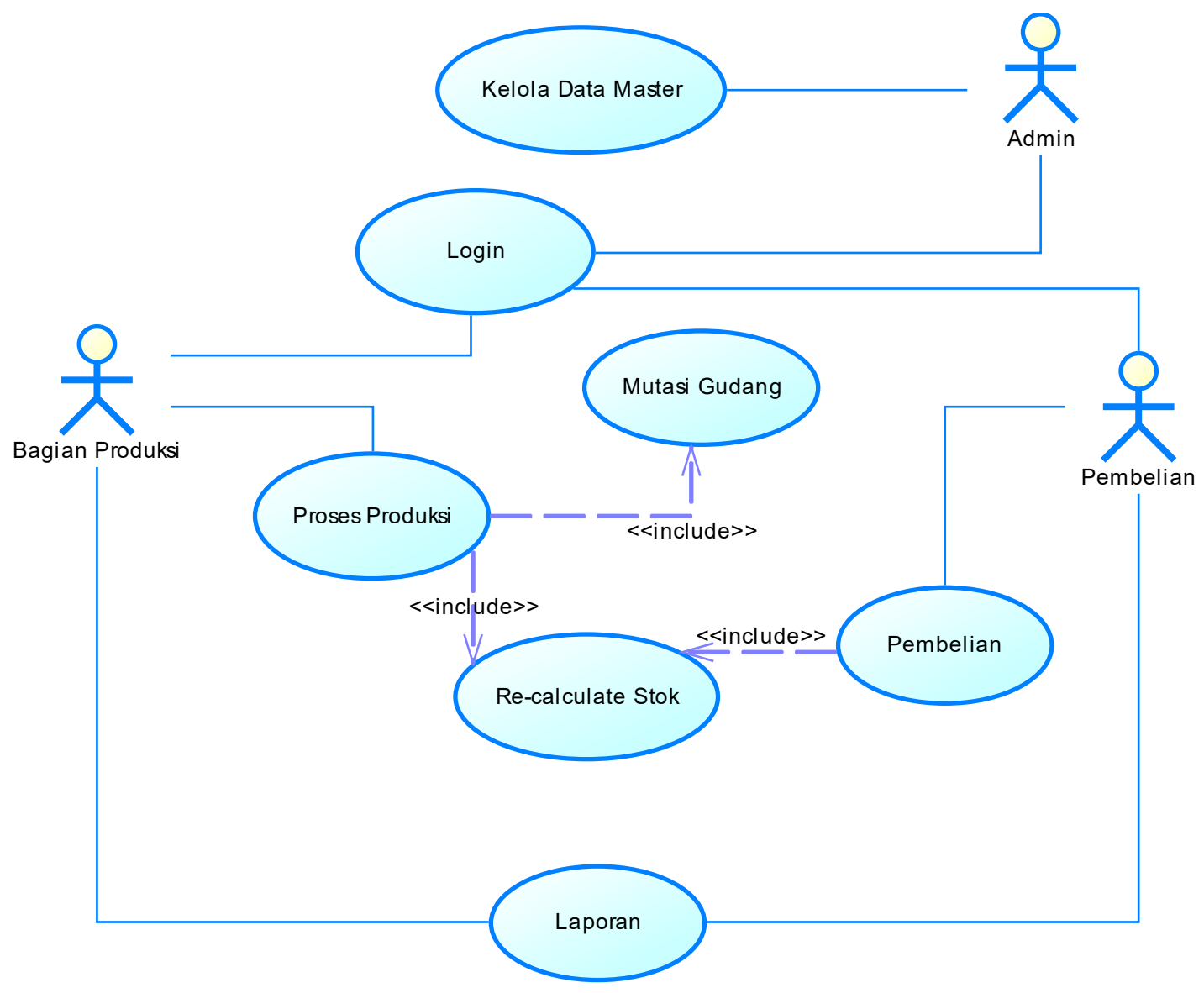

Gambar 1. Use Case Diagram

\section{Use Case Diagram}

Pada Gambar 1menujukkan use case diagram sistem produksidn persediaan UMKM. Dalam use case diagram terdiri dari 3 aktor yaitu, Bagian Produksi, Pembelian dan Admin. Dimana setiap aktor mempunyaihak akses terhadap fungsi sendiri-sendiri. 


\section{Activiy Diagram}

Berdasarkan dari analisa kebutuhan yang telah dilakukan, maka aktivitas diagram dari sistem diunjukkan pad gambar 2 dan 3. Gambar 2 menunjukkan activity diagram Login sebagai autorisasi user dalam mengakses sistem yang dibangun. Gambar 3 menunjukkan activity diagram proses produksi yang dilakukan UMKM. Proses produksi dilakukan berdasarkan atas persedian stok barang siap jual atau berdasarkan order pembelian. Dimana produksi berdasarkan stok dipengaruhi akan jumlah penjualan tanpa order yang dilakukan pada proses penjualan. Sedangkan proses produksi berdasarkan order penjualan dilakukan pada item-item produk dan kuantitas sesuai dengan order beli. Hal ini dilakukan supaya tidak terjadi penumpukan hasil produksi.

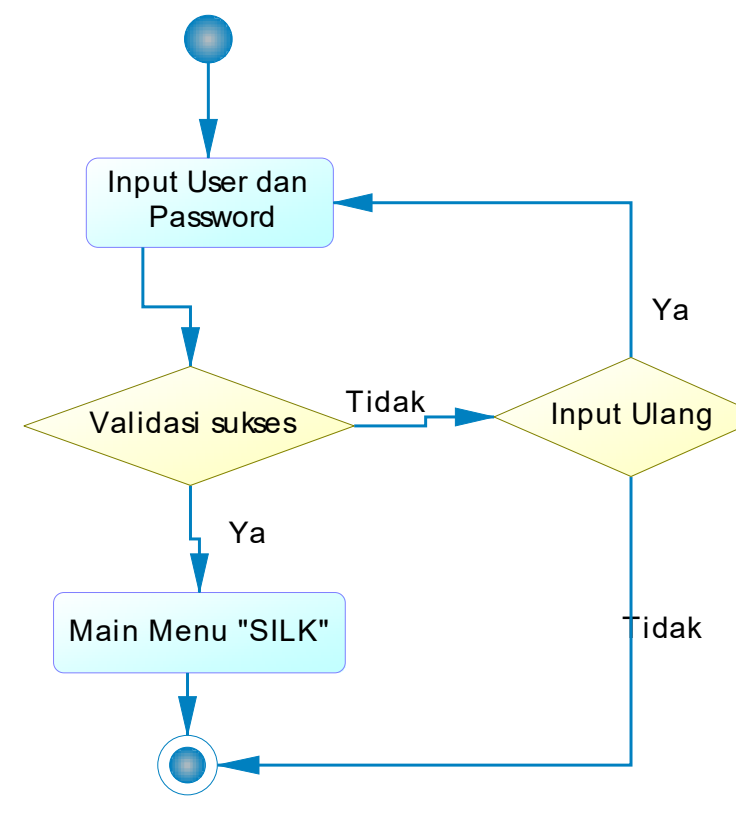

Gambar 2. Activity Diagram Login

Gambar 4 menunjukkan activity diagram pembelian. Pada proses pembelian bisa dilakukan pembelian secara tanpa order pembelian ataupun pembelian dengan order pembelian. Jika pembelian dilakukan tanpa order pembelian stelah load form pembelian user bisa langsung menginputkan data pembeliannya.

Sedangkan pembelian dengan oorder pembelian pada setelah load form pembelian pilih nomor order pembelaian untuk mengeluarkan barang-barang beserta jumlah yang akan dilakukan proses pmbelian. 
Rinci Kembang Hapsari, Azmuri Wahyu Azinar, Sugiyanto, Rancang Bangun Sistem Produksi dan Persediaan UMKM

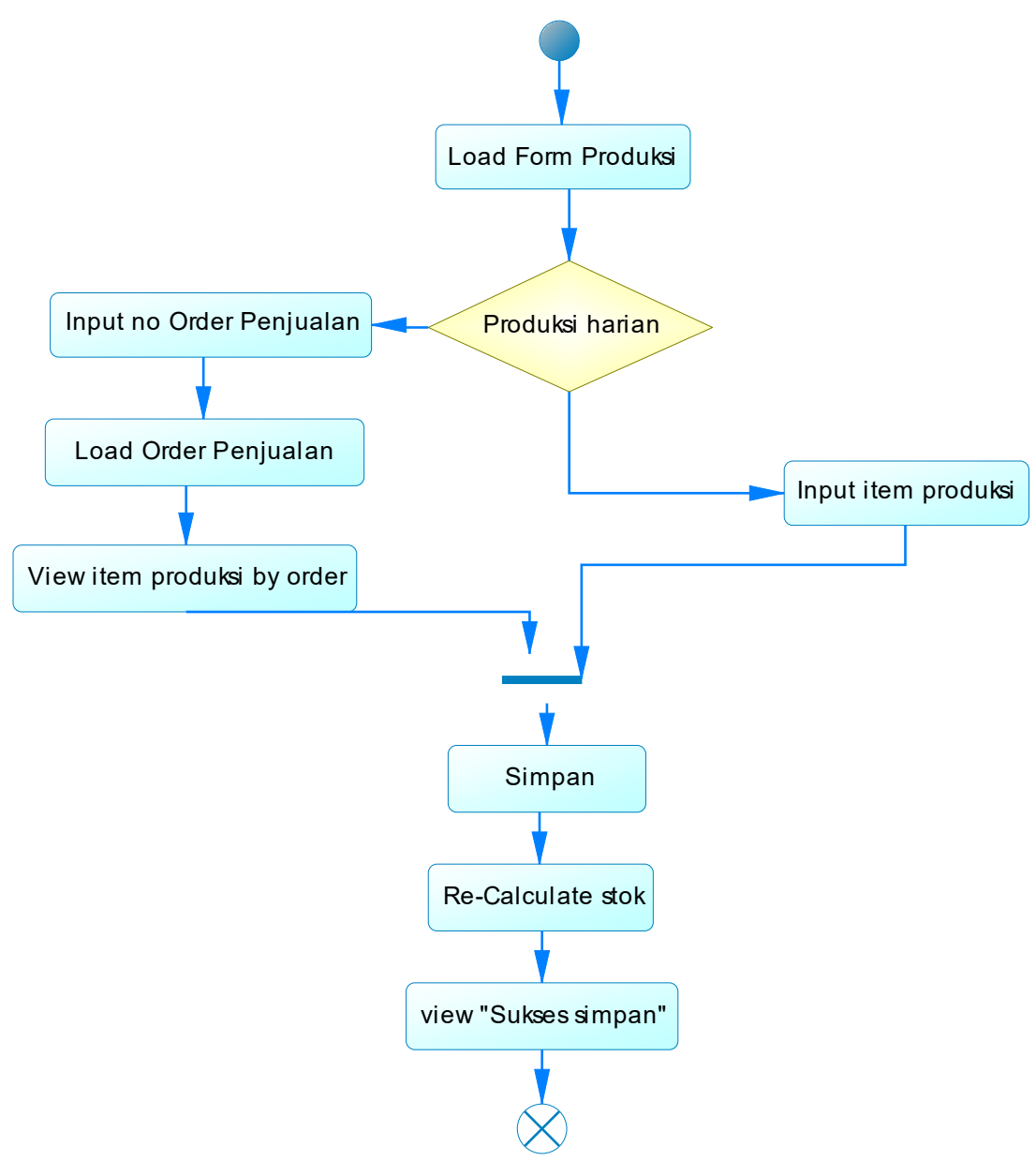

Gambar 3. Activity Diagram Proses Produksi

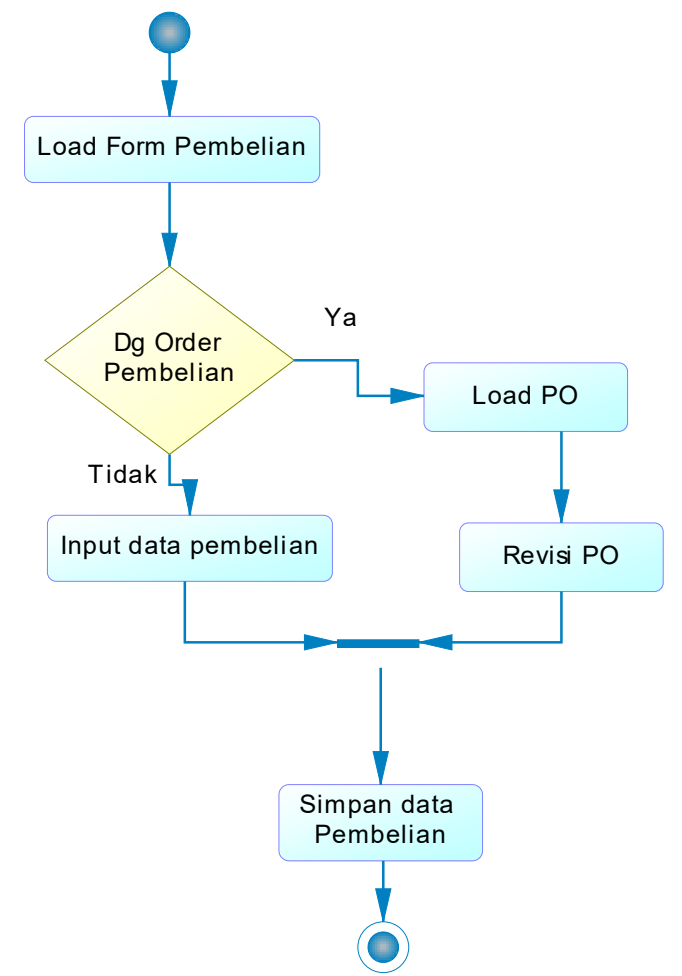

Gambar 4. Activity Diagram Pembelian 


\section{KESIMPULAN}

Setelah melakukan penelitian ini dpat diambil kesimpulan bahwa :

a) Denngan sistem terkomputerisasi yang dikembangkan mampu mengurangi kesalahan pencatatan stok barang karena sistem akan melakukan perubahan stok barang secara otomatis setiap melakukan transaksi produksi yang dilakukan UMKM.

b) Dengan adanya sistem terkomputerisasi dapat membantu UMKM dalam melakukan monitoring persediaan karena data produksi terpantau secara cepat dan akurat. Sehingga dapat mengurangi terjadinya penumpukan stok barang maupun terjadinya stok barang kosong dalam waktuyang lama.

c) Penerapan sistem terkomputerisasi ini juga bermanfaat dalam membantu bagian produksi dan gudang dalam membuat laporan yang dibutuhkan sehingga membantuUMKM dalam mengambil keputusan.

\section{DAFTAR PUSTAKA}

Keputusan Menteri Ketenagakerjaan Republik Indonesia, Nomor 136 Tahun 2016, tentang "Penetapan Standar Kompetensi Kerja Nasional Indonesia Kategori Jasa Profesional, Ilmiah dan Teknis Golongan Pokok Kegiatan Kantor Pusat dan Konsultasi Manajemen Bidang Sistem Manufaktur"

Nasution, Hakim, Prastyawan, Yudha. 2008 "Perencanaan dan Pengolahan PRoduksi”. Graha Ilmu: Surabaya.

Hansen, Don R. \& Maryanne M.Mowen. 2009 "Managerial Accounting : Akuntansi Manajerial”. Jakarta : Salemba Empat.

Cecily A. Raiborn dan Michael R. Kinney. 2011 "Akuntansi Biaya: Dasar dan Perkembangan”. Buku 1, Edisi 7, Salemba Empat, Jakarta.

Carter, William K. 2009 “Akuntansi Biaya”. Buku Satu. Edisi Empat Belas. Salemba Empat. Jakarta.

Daljono.2011 “Akuntansi Biaya, Penentuan Harga Pokok dan Pengendalian”. Edisi Ketiga. Cetakan Kedua. BP Undip. Semarang.

Rangkuti, Freddy. 2004 "Menejemen Persediaan". Jakarta: Aplikasi Bidang Bisnis Raja Grafindo Persada.

Dewi Agustini Santoso, Ari Haryono, 2011 "Rancang Bangun Sistem Informasi Perencanaan dan Pengendalian Bahan Baku Pada Industri Pakaian” Jurnal Techno Science Vol 5 No. 2 Oktober 2011

Stephanie Surja, Lius Steven Snjaya. 2014. "Perancangan Sistem Produksi, Persediaan, Dan PEmbelian PT. Jaya Mulya" ComTech Vol 5 No. 1 Juni 2014: 1-13 